\title{
A GEOPOLÍTICA DA GUERRA DO GRUPO ESTADO ISLÂMICO: A AMEAÇA DO TERROR SEM ROSTO
}

\author{
Cleidson Gomes de Oliveira ${ }^{1}$ \\ Dante Severo Giudice ${ }^{2}$
}

\section{Resumo}

Este artigo é um estudo sobre a origem do grupo terrorista Estado Islâmico (EI), as formas de atuação das suas ações pela região do Oriente Médio local onde o mesmo foi criado, e em outros países que se opuseram e se opõem à formação do seu califado, como os Estados Unidos da América, alguns países europeus e partes da Ásia. Este trabalho mostrará todos os territórios pretendidos e conquistados pelo grupo terrorista na Síria e no Iraque no início da sua formação assim, como, também, as regiões que eles almejavam conquistar fora do mundo árabe, bem como as regiões que eles perderam para os exércitos dos países, que com eles lutam diretamente para essa reconquista territorial. Vale ressaltar que o grupo utiliza-se de métodos como as redes sociais e a própria internet para divulgar seus atos e atrair jovens do mundo todos para fazer parte de seus propósitos.

Palavras-chave: Estado Islâmico, Terror sem rosto, Alcorão, Terrorismo, Profeta Maomé.

\section{THE GEOPOLITICS OF THE WAR OF THE ISLAMIC STATE GROUP: THE THREAT OF TERROR WITHOUT FACE}

\begin{abstract}
This article is a study about the origin of the terrorist group Islamic State (IS), and the ways of their actions by the regions of the Middle East, where the same was created and in other countries that opposed and are opposite to the formation of their caliphate, such as the United States of America, some European countries and some areas from Asia. This work will show all the territories intended and conquered by the terrorist group in Syria and Iraq at the beginning of their formation as well as the regions they were aiming to conquer outside the Arab world and the regions they lost to the Armies from the countries, which with them fight directly for the reconquest territorial. It is noteworthy that the group uses methods such as social networks and the Internet itself to disseminate their acts and attract young people from all over the world to join their purposes.
\end{abstract}

Key-words: Islamic State, Faceless Terror, Koran, Terrorism, Prophet Muhammad.

\footnotetext{
1 Especialista em Gestão e Auditoria Ambiental pela Escola de Engenharia Eletro-Mecânica da Bahia EEEMBA, Graduado em Geografia pela Universidade Católica do Salvador - UCSal. Atualmente é professor Colégio Damazzio, membro pesquisador do Grupo de Pesquisa de Estudo e Pesquisa em Geografia Política e Geopolítica- GEPOGEO. E-mail: cleidsongeohumanas@gmail.com.

${ }^{2}$ Professor do IFCH/UCSAL. Curso Geografia. Dr. em Geografia pela UFS. Geólogo Sênior da CBPM, Salvador-BA, Brasil. Líder do Grupo de Estudo e Pesquisa em Geografia Política e Geopolítica-GEPOGEO. Email: dasegu@gmail.com.
} 


\section{LA GEOPOLÍTICA DE LA GUERRA DEL GRUPO ESTADO ISLÁMICO:LA AMENAZA DEL TERROR SIN ROSA}

\section{Resumen}

Este artículo presenta un levantamiento sobre el origen del grupo terrorista Estado Islámico (EI), sus formas de actuación y sus acciones terroristas por todo Medio Oriente, donde el mismo fue creado, así como en otros países que se opusieron y se oponen a la formación de su califato fuera de esas fronteras, como los Estados Unidos de América, algunos países europeos y partes de Asia. Este trabajo mostrará todos los territorios pretendidos y conquistados por el grupo terrorista en Siria e Irak al inicio de su formación, y también las regiones que deseaban conquistar fuera del mundo árabe, como las regiones que ellos perdieron para los ejércitos de los países que con ellos, luchan directamente hacia esa reconquista territorial. Como el grupo se utiliza de métodos como las redes sociales y la propia internet para divulgar sus actos y atraer a jóvenes del mundo todos para formar parte de sus propósitos.

Palabras-clave: Islámico, Terror sin rostro, Corán, Terrorismo, Profeta Mahoma.

\section{INTRODUÇÃO}

Os povos como do Império Otomano, os Persas, os Babilônico, o antigo Egito, o Império Romano e muitos outros, desde o início dos tempos se enfrentam em guerras e batalhas, conquistando territórios e escravizando pessoas para lhes servirem; povos esses, que eles achavam ser inferiores às suas raças ou às suas castas. Seus objetivos eram conquistar novas terras e expandir suas fronteiras de domínios, e assim, ampliar os seus impérios, tomar para si - tesouros e riquezas dos países conquistados. Naquela época, o que fazia uma nação ser poderosa era a dimensão de seus domínios territoriais, o contingente de soldados, a experiência e a força dos seus exércitos. Tudo isso atrelado ao tamanho das suas riquezas ( ou os espólios de guerras); quanto maior a sua fortuna, mais poderosa e temida seria esta nação.

No período do século $\mathrm{XX}$, não foi tão diferente dos séculos anteriores; o mundo enfrentou duas grandes Guerras Mundiais, e também presenciou uma guerra "bilateral" - à "Guerra Fria", onde os maiores protagonistas desses conflitos estavam em lados opostos tentando conquistar através da "força política/econômica" e da destruição de nações menores e menos pujante, à hegemonia de um mundo dividido, sendo que os países menores faziam o papel de meros coadjuvantes nesta "seara" de intrigas internacionais.

Dividindo o papel de protagonista da trama, estava de um lado, o lado Oeste, os Estados Unidos da América (EUA) com o seu recém criado regime capitalista que dominava a 
parte Ocidental do planeta e, do outro lado, no lado Leste, à antiga União das Repúblicas Socialistas Soviéticas (URSS) com seu regime socialista e seus subjugados.

Outros países não menos importantes economicamente do que esses dois primeiros, como Grã-Bretanha e França, gravitavam na órbita, ao lado dos estadunidenses, apoiando-o nos seus interesses geopolíticos, econômicos e estratégicos desse mundo "bipolarizado".

$\mathrm{O}$ século $\mathrm{XX}$, se caracteriza pelos conflitos entre as nações mais poderosas que dominam o poder econômico e político e as nações "do terceiro mundo", na disputa por territórios e o controle de fontes de energias, para suprir suas necessidades internas.

A partir do meado do século XX, e início do século XXI, esses conflitos vêm mudando de configuração, quando deixam de ser diretamente entre nações que têm sua "soberania" reconhecida entre as organizações mundiais, e começam a se deflagrar entre grupos independentes paramilitares que se denominam nacionalistas e, doravante, lutam contra o regime autoritário de governos dos seus próprios países, como acontece em alguns países africanos, em praticamente toda a região do Oriente Médio, em outras partes do continente asiático, e até mesmo em alguns países do continente americano, como ocorreram as Revoluções na América Latina por parte de revolucionários paramilitares, onde desencadearam os Golpes de Estados, e as Ditaduras Militares, inclusive no Brasil, regime comandado com mão de ferro e autoritarismo pelas forças armadas nacionais.

Muitas vezes, esses sentimentos de nacionalismo adotados pelas pessoas diretamente envolvidas nos conflitos, onde precede uma "divergência ideológica no âmbito das questões políticas e de crenças religiosas", e que essa última, têm lideranças com um poder de manipulação e de influência religiosa muito forte, principalmente no Oriente Médio, esses sentimentos vêm de países árabes ligados à sharia.

Esse nacionalismo acaba por confundir-se com religião e transformam-se em grupos de tendências religiosas radicais, com fundamentação no "jihad" e de características extremistas voltadas para as práticas de sequestros, torturas, terrorismos e mortes, impostas contra pessoas que não se converterem ao islamismo ou que se oponha a tal. Esses grupos são mais comuns em países de religião islâmica, tem o "Alcorão" como livro sagrado, e Maomé como o seu único profeta e líder religiosolespiritual; exemplo disso, foi o surgimento do grupo jihadista com características de ações e condutas extremistas - com o "Estado Islâmico" (EI).

Em se tratando de uma análise mais particular e superficial sobre o entendimento do que é território, por não ser aqui, nosso principal objetivo, e, sim, as condutas de ações e 
origem do grupo terrorista Estado Islâmico; analisando-os sob à luz do pensamento de alguns autores que levam essas interpretações por viés distintos, como a definição do território conquistado, o território pretendido e o território pura e simplesmente ocupado por questões de povoamento; verificou-se que cada autor tem sua interpretação em particular.

Sobre o entendimento de território conquistado, Faissol (1994), "considera que território ainda é a forma de organização política, onde um sistema de autoridade pode ser instituído, seja pelo consentimento, seja pela força". Este conceito de território pelo poder e pela força, é o que mais condiz com os ideais do grupo terrorista Estado Islâmico (grifo nosso). Já no entendimento de Santos (1999, p.19) sobre o território pretendido, ele ressalta que:

Na democracia de mercado, o território é o suporte de redes que transportam regras e normas utilitárias, parciais, parcializadas, egoístas (do ponto de vista dos atores hegemônicos), as verticalidades, enquanto as horizontalidades hoje enfraquecidas, são obrigadas, com suas forças limitadas, a levar em conta a totalidade dos atores (SANTOS, 1999, p.19).

Sobre esse entendimento do território pretendido na democracia de mercado, são as grandes corporações que avançam sobre o território, e dominam o mercado com seu poder econômico e hegemônico, muitas vezes monopolizando o setor de sua atuação.

Raffestin (1993, p. 143), faz um julgamento sobre suas convicções do que é território, ao partir, da análise do que antes do surgimento do território, já existia o espaço. Então, ele "corrobora" com uma abordagem do conceito de espaço e território, dizendo que:

É essencial compreender bem que o espaço é anterior ao território. O território se forma a partir do espaço, é o resultado de uma ação conduzida por um ator sintagmático (ator que realiza um programa) em qualquer nível. Ao se apropriar de um espaço, concreta ou abstratamente (por exemplo, pela representação), o ator "territorializa" o espaço. Lefebvre mostra muito bem como é o mecanismo para passar do espaço ao território: "A produção de um espaço, o território nacional, espaço físico, balizado, modificado, transformado pelas redes, circuitos e fluxos que aí se instalam: rodovias, canais, estradas de ferro, circuitos comerciais e bancários, autoestradas e rotas aéreas etc."2. O território, nessa perspectiva, é um espaço onde se projetou um trabalho, seja energia e informação, e que, por consequência, revela relações marcadas pelo poder. 0 espaços é a "prisão original", o território é a prisão que os homens constroem para si. (RAFFESTIN, 1993, p.143).

Este tema, “A GEOPOLÍTICA DA GUERRA DO GRUPO ESTADO ISLÂMICO: A AMEAÇA DO TERROR SEM ROSTO”, é bastante apropriado e, tem uma relevância muito forte para o desenvolvimento e a execução deste trabalho. Não existe na literatura um 
conceito formulado para essa expressão. Por isso, o que se "discorre" a seguir, sobre o assunto, é uma conceituação particular do próprio autor, para que não se caracterize um “jargão ou termo midiático". Esse é um tema recente e carente de publicações que ofereçam conteúdo para uma melhor fundamentação. O termo "o terror sem rosto", sem entrar em uma nova dialética, é explicitado no texto, que a nossa proposta se deve ao fato de que o grupo terrorista Estado Islâmico, atua de maneira global pelas redes, na clandestinidade, de forma obscura, recrutando adeptos ao redor do mundo, como aconteceu com a jovem alemã detida em Mossul, no Iraque EL PAÍS (2017), e em outros países da Europa, além de outros continentes. Ele se refere assim, a um movimento que incentiva o terrorismo, mas não tem um líder definido nem um país como sede.

É um processo de estímulo que transcende países, nações, ideologias, mas que não tem uma "marca", uma "cara". Uma "célula terrorista", quando quer propagar o terror à uma cidade, embora pretenda atacar/atingir também países não muçulmanos, principalmente, os que se "balizam" em pensamentos e atitudes com os Estados Unidos da América, são considerados por eles infiéis, essas pessoas podem se camuflar, podendo ser qualquer pessoa que esteja ao nosso lado, sem que saibamos do seu real interesse ou atitudes à serem tomadas por eles naquele momento. Daí, o termo ("terror sem rosto"), por não podermos identificar quem são essas pessoas.

Esses grupos terroristas vêm mudando as táticas e as formas de enfrentarem seus inimigos, fazendo "guerras veladas" contra nações no mundo inteiro.

Há algum tempo atrás, às guerras eram entre países que de certa forma conheciam os seus inimigos e as estratégias usadas em conflitos. Hoje as ameaças surgem de pequenos grupos de pessoas ou de "células solitárias" como são conhecidas as pessoas que agem sozinhas, de forma isolada. Seus componentes podem estar em qualquer lugar do mundo, e pode ser qualquer um em meio à uma multidão de pessoas comuns/civis.

Essas prerrogativas que influenciam essas pessoas, são o que acaba por dificultar sua identificação; e, por outro lado, deixa os países "alvos" desses grupos, vulneráveis a todos os tipos de ataques surpresa. O autor do livro "Geopolítica do Caos” Ignácio Ramonet (1998, p. 7-8), tem opiniões bastante abrangentes no seu modo de ver e de perceber as turbulências em que o mundo contemporâneo está se inserindo, no contexto de conflitos e ameaças de um novo tipo.

Do seu ponto de vista geopolítico/geoeconômico e estratégico, ele relata que: 
"[...] o mundo apresenta o aspecto de um grande caos: por um lado, multiplicações das uniões econômicas regionais (União Europeia, NAFTA, Mercosul, APEC...); por outro, o renascimento dos nacionalismos, ascensão dos integrismos, Estados divididos, minorias que reivindicam sua independência. Neste final de século, a maioria dos conflitos (Argélia, Albânia, Bósnia, Chechênia, Curdistão, Afeganistão, Chiapas, Sudão, Libéria, Congo-Zaire, Ruanda, etc.) são conflitos internos, interestatais, que opõe um poder central a uma fração da sua própria população. Além disso, redes internacionais de caráter mafioso e o crime organizado constitui novas ameaças porque controla toda espécie de circuitos clandestinos (prostituição, contrabando, tráfico de drogas, venda de armas, disseminação nuclear) [...]" (RAMONET,1998, p. 7-8).

São essas situações segundo o autor, que levam os países aos conflitos internos (intraestatais). O Estado toma medidas políticas e econômicas que causam grandes insatisfação da população. Por sua vez, essa insatisfação e as instabilidades regionais, fomentam o surgimento de grupos que reivindicam melhores condições de vida para a população. Entretanto, alguns deles preferem o caminho mais radical, como é o caso do grupo terrorista Estado Islâmico, que é o objeto de estudo desse trabalho.

\section{METODOLOGIA}

Procurou-se conduzir a metodologia dessa pesquisa para uma concepção Hipotéticodedutivo, ao qual, busca-se a verdade, eliminando toda e quaisquer possibilidades de afirmação falsa. Para (LAKATOS \& MARCONI 2000, p. 75), conforme citado por (DINIZ \& SILVA, 2008, p. 09)

As hipóteses tornam-se as "supostas verdades" ou "meias verdades", sobre os fenômenos que foram problematizados enquanto objeto de estudo científico, dadas à verificação por meio de experimentações e testes. Compreende-se que esse método pressupõe as bases teóricas dedutíveis a fenômenos particulares que refutarão ou corroborarão com a teoria em teste. Nesse caso, "a observação é precedida de um problema, de uma hipótese, enfim, de algo teórico", conforme Lakatos; Marconi (2000, p. 75). Conforme citado por Diniz e Silva (2008, p. 09). Esse método vem contribuir com a criação de novos pressupostos teóricos para pesquisa científica.

O hipotético dedutivo, parte da criação de uma ideia na qual ainda não foi provada como verdadeira. Sua base ainda está relacionada com o fundamento de hipótese, precisando ser um pouco mais debatida por outros pensamentos diferentes, para que se chegue a um denominador comum. Ao alcançar esse estágio de concordância unanime, aí, é que se decide pela fórmula metodológica de uma pesquisa. Como o tema do artigo é um tema bastante 
polêmico e abrangente, e que demanda a opinião de vários profissionais para expor suas críticas, foi pensando no debate crítico e democrático que inserimos este método ao trabalho.

O presente trabalho nos proporcionará conhecer um pouco mais da origem, do perfil de atuação e objetivos pretendidos por esse grupo terrorista, que nos últimos anos vêm sendo considerado o mais perigoso pelos seus atos terroristas, e economicamente, um dos mais ricos. Desta forma, vem ganhando espaço, conquistando à força, territórios e recrutando jovens do mundo inteiro através de redes sociais. Os jovens se encantam pelo perigo e transformam-se em adeptos do "extremismo radical"; estão dispostos a "matar e a morrer" por um ideal que não se sustenta, não tem justificativas plausíveis, e tampouco, fundamentos que deem notoriedade às essas investidas violentas contra a população civil, não só nos seus países de origem, mas também nas demais nações ao redor do mundo.

É preciso destacar que, é muito difícil desenvolver uma pesquisa com tal complexidade temática, onde são demandados minuciosos cuidados nas discussões ao longo do texto, para não "dirimir" por completo, tudo o que foi feito ao longo dessa incessável jornada; quando se tem uma limitação em adquirir bibliografias consistentes e seguras que explane sobre o tema.

Para tanto, foi feito um levantamento bibliográfico em obras de fontes primárias e secundárias que tratam do assunto em questão. Procurou-se pesquisar e selecionar um conteúdo idôneo que servisse de fundamentação teórica para dar notoriedade ao trabalho como - livros, artigos, site de pesquisas. Utilizou-se também como fonte de pesquisa, alguns trechos da (Bíblia Sagrada e uma tradução para a língua portuguesa do Alcorão, o livro sagrado da religião Islâmica), traduzido por (Samir El Hayek em abril de 2006).

Esta leitura tornou-se indispensável para que pudéssemos identificar nas passagens das "Suratas" (capítulos) deste livro, se poderíamos encontrar alguma mensagem onde esses grupos possam interpretar de forma equivocada, e fazer dessas palavras, suas justificativas para promoverem atentados à bomba, sequestros e mortes de "jornalistas e de pessoas inocentes" sem qualquer remorso, já que os "radicais" que seguem a Sharia, dizem que se baseiam nas palavras do Alcorão para matar em nome de Allah, (Deus em português).

\footnotetext{
${ }^{3}$ Surata: é a denominação dada aos capítulos do Alcorão, o livro sagrado do povo muçulmano de religião Islâmica.
} 


\section{A CIDADE DE MECA, MAOMÉ - O LIDER ESPIRITUAL E PROFETA DO MUNDO ISLÂMICO E AS REVELAÇÕES DO ALCORÃO}

\section{A origem da cidade de Meca}

De acordo com Kamel (2007, p. 42-43), à cidade de Meca surgiu em meio ao deserto, quando Abraão não atendendo (segundo relatos), a um pedido de sua esposa Sarai, mas, sim, de Deus - ele expulsou de sua tribo, a sua serva Agar, com quem teve um filho chamado Ismael. Depois de vagarem dias e noites por vales montanhosos e desertos escaldantes, o menino com muita sede começa a chorar e a empurrar a areia com os pés, escavando o chão; nesse momento, depois do anjo Gabriel ouvir os lamentos de sua mãe Agar, implorando por ajuda, à água começa a brotar da areia escavada.

Viajantes beduínos que passavam por ali constantemente, com suas caravanas, começam a fazer pousada no local por causa da água que brotara do chão. A partir daí, começou a surgir a cidade de Meca que na época, se tornou um Centro Comercial muito importante na região por causa da sua localização geográfica.

A cidade de Meca se tornou importante pelos milhares de peregrinos adeptos à religião islâmica, que pelo menos uma vez na vida, os muçulmanos vão até lá, para participar do "Haje", nome dado à peregrinação, e pela aproximação com o "Próximo Oriente"; uma região situada nos planaltos da Palestina, ou Montanhas do Líbano, que recebem chuvas abundantes do mar, formando uma área úmida que os ingleses no século XIX, chamavam de "Crescente Fértil", e os gregos da antiguidade chamavam de Mesopotâmia. A região foi por muito tempo a passagem entre as rotas que iam de Meca para Norte, para Istambul na Turquia, ou para Sudeste, e para o Golfo Pérsico (LACOSTE, 2006, p. 393).

\section{Maomé - O profeta do Islã}

O "amado, o glorificado"! Assim era conhecido Maomé pelo povo de sua tribo, os "Coraixitas" ou (quraysh), e por todo o povo de religião islâmica. Segundo relato de Kamel (2007, p. 63), o profeta Maomé nasceu na cidade de Meca por volta do ano 570. Ele vem de uma descendência que tem ligação direta com Deus. Maomé descende dos profetas Ismael, Abraão e Noé; essa descendência talvez tenha sido um dos principais motivos para que Deus o tenha escolhido como o seu último profeta para pregar as suas palavras na Terra.

Maomé, ou Muhammad, como é falado em árabe, perdeu o seu pai ainda antes de nascer; sua mãe Aminah, morreu quando Maomé tinha ainda apenas seis anos de idade; o 
menino passa a ser criado pelo avô paterno Abdu L' Muttalib, que vem a falecer dois anos depois.

Aos quarenta anos de idade, Maomé já muito mais experiente e reflexivo, começa a se refugiar durante dias e noites em cavernas aos arredores da cidade peregrina de Meca para meditações; em uma dessas meditações segundo Kamel (2007, p. 66-67), Maomé recebe a visita do Arcanjo Gabriel, que pede para Maomé recitar as palavras que estavam diante dele; essas palavras seriam as primeiras revelações dos cinco primeiros versículos da "sura" 96, que Deus transmitira através do anjo para o profeta, e depois seriam propagadas por todo o mundo muçulmano.

Em nome de Deus, o Clemente, o Misericordioso.

1 - "Lê $\hat{e}^{(1899)}$, em nome ${ }^{(1900)}$ do teu Senhor que Criou”;

2- "Criou o homem de algo que se agarra(1901)".

3- "Lê, teu senhor é Generosíssimo”,

4- "Que ensinou através do Cálamo4(1902),

"Ensinou ao homem o que este não sabia" (O ALCORÃO. AL 'ALAC, 96:1-5, o Coágulo, p. 714).

\section{As revelações do Alcorão}

Para podermos entender um pouco mais do que se é noticiado constantemente nos veículos de comunicações pelo mundo, foi preciso com muita dedicação, nos debruçarmos durante alguns meses em uma leitura de 1322 páginas, de uma cópia do Alcorão com 114 capítulos traduzido para o português por Samir El Hayek, que fala sobre as atitudes radicais promovida por pessoas ou grupos extremistas, que se dizem membros da religião islâmica, e se fundamentam nas suratas do alcorão, para praticarem atividades violentas em nome de Allah (Deus em português).

Admite-se que para termos uma visão geral e contextualizada do assunto em questão, precisaríamos ser pelo menos um conhecedor autêntico das ciências filosóficas e teológicas, para decifrarmos as passagens do Alcorão, que se faz por muitas vezes enigmáticas.

Entretanto, o tradutor do alcorão Samir El Hayek faz algumas ressalvas já na introdução do livro sagrado, de que o mesmo fora revelado a Maomé sempre por intermédio do anjo Gabriel nas cidades de Meca e Medina, por praticamente toda sua vida, de forma

\footnotetext{
${ }^{4}$ Cálamo: é um instrumento para a escrita, feito de um pedaço de cana ou junco, talhado obliquamente ou
} afinado na extremidade, utilizado antigamente para escrever em tábuas de argila, papiros e pergaminhos. 
fragmentada, de capítulo em capítulo e escrito em diversos tipos de materiais rudimentares, como pedras, papiros, folhas de tamareiras, couro de camelos e até em ossos de animais. Para Kamel (2007, p. 74-75), essas escrituras poderiam se perder com o passar do tempo se não fossem juntados em um só material, e assim, poderiam ser reescritos de forma diferente da originalidade, e que poderiam ser interpretados de forma tendenciosa em benefício próprio de uma minoria.

Por isso, por volta do ano 650 d.C., depois da morte do profeta no ano 632 d.C., o Califa Omar preocupado com as mortes de pessoas que sabiam recitar de cor as palavras que Deus havia revelado a Maomé, e que essas palavras se perdessem no tempo por causa das constantes guerras, ele resolve compilar todos os manuscritos que até outrora estavam escritos separadamente em diversos materiais - os juntou em um só livro que conhecemos hoje como Alcorão.

As evidencias e os significados que o Alcorão abrange, já citados, só podem ser entendidos através do texto alcorânico e de seus versículos. Tal explicação é uma pesquisa sobre a vontade de Deus, sobre o conhecimento dessa vontade através de suas palavras no Alcorão. [...] $\mathrm{Na}$ época da revelação do Alcorão, enquanto o profeta vivia, não havia necessidade para explicação dos versículos, nem a regulamentação dessa ciência, porque o texto, na sua totalidade, era claro, compreensível para o profeta e seus companheiros. A pesar disso, o profeta explicava alguns versículos e algumas pronuncias que podiam causar ambiguidades; também os companheiros do profeta e alguns adeptos assim o fizeram. Isso porque poderia haver uma má interpretação, quaisquer que fossem as razões que tinham de se desenrolar na alvorada de um povo progressista em formação, que iria se expandir através de conquistas, enriquecendo sua existência com acontecimentos históricos, discussões, doutrinas e pesquisas em jurisprudência e política (O ALCORÂO, 2006, p. 6-7).

Tomando como base o último parágrafo da citação acima, e temendo que as pessoas pudessem fazer má interpretação das palavras de Deus, preocupado que os manuscritos começassem a se perder com o passar dos anos, correndo o risco de serem reescritos por pessoas ao seu bel entender e conveniência, o Califa Omar se preocupou em juntar todos os manuscritos na época, resultando em um só livro, com 114 suratas, mantendo o máximo de sua originalidade possível.

Sabe-se que o livro do Alcorão não prega qualquer tipo de violência contra nenhum dos povos, religião ou país. Mas sim, benevolência e adoração a Deus, (o clemente, o misericordioso). Mas, em nossa leitura, conseguimos identificar em algumas suratas, passagens em que os seguidores do Alcorão poderiam interpretá-las de forma equivocada, 
para justificar os seus atos mais radicais, como atentar contra o seu próprio povo ou contra alguma nação que se opusesse aos seus ideais e objetivos religiosos e políticos.

\begin{abstract}
Em conteúdo, o Alcorão consiste num conjunto de preceitos e recomendações éticas e morais, advertências sobre a chegada do último dia e juízo final, histórias sobre profetas anteriores a Maomé e povos a quem foram enviados, preceitos sobre religião, vida social, matrimônio, divórcio ou herança. A mensagem, em essência, é que existe um só Deus, criador de todas as coisas, ao qual há que se servir, praticando o culto e observando conduta correta. Deus é sempre misericordioso e tem se dirigido à humanidade para que ela o venere nas pessoas dos diversos profetas enviados por ele (GONÇALVES, 2017).
\end{abstract}

Começamos por identificar algumas das revelações que poderiam ser mal interpretadas na surata $47^{\text {a }}$, versículo 4, de "Mohammad", onde as palavras expressam-se dessa forma:

E quando vos enfrentardes com os incrédulos ${ }^{(1493)}$, (em batalha), golpeai-lhes o pescoço, até que os tenhais dominados ${ }^{(1494)}$, e tomai (os sobreviventes) como prisioneiros. Libertai-os, então, por generosidade ou mediante resgate ${ }^{(1495)}$, quando a guerra tiver terminado. Tal é a ordem. E se Deus quisesse. Ele mesmo ter-se-ia livrado deles; porém, (facultou-vos a guerra) para que vos provásseis mutuamente. Quanto àqueles que foram mortos pela causa de Deus ${ }^{(1496)}$, ele já mais desmerecerá as suas obras (O ALCORÃO. MOHAMMAD, 47:4. MAOMÉ, p. 564).

No mundo árabe, os relatos de guerra remetem-se desde o tempo em que os hebreus saíram do Egito em busca da terra prometida por Deus. Em sua jornada de 40 anos pelo deserto, os hebreus tiveram que aprender a lutar e formaram um dos maiores e mais poderosos exércitos da época; muitas passagens do Velho Testamento também descreve as conquistas do povo de Deus em batalhas para chegarem ao seu destino.

$\mathrm{Na}$ parte do livro do Alcorão que foi reservado para a nota do autor, as revelações relatam uma passagem do livro de Êxodo (32:27-28, p. 122), que diz assim: - as palavras de Moisés estão construídas literalmente de forma branda, reproduzindo o Êxodo perfeitamente. Por outro lado, o Velho Testamento diz:

"[...] passai e tomai pelo arraial de porta em porta, que mate cada um a seu irmão, e cada um a seu amigo, e cada um a seu próximo [...] houve uma ordem de escravidão, por meio de julgamento, que foi retirada porque Deus os perdoou [...]" (O ALCORÃO, 2006, 19, p.739).

Em uma outra passagem na nota do autor, no versículo 80, da página 763, do Alcorão (2006), vem mostrar algumas das obrigações dos povos daquela época, nas formas de fazerem guerra em nome de Deus. O trecho do Alcorão citado acima, ressalta que toda luta requer "meios diversos" para os seus preparativos. Ele quer dizer que, esses eventos demandam muitos recursos financeiros e logísticos para serem realizados. No seu entendimento, se a guerra é justa, e em nome de Deus, todos aqueles que direta ou indiretamente estejam envolvidos nesta guerra, os que possuam bens financeiros ou materiais, devem contribuir 
espontaneamente de alguma forma para que esta guerra aconteça. Nos escritos do Alcorão, isso dá a entender que todos devem fazer sua parte. Essa deve ser a sua contribuição pessoal para terem êxito na causa de Allah [...].

O próprio Maomé foi um dos grandes soldados que lutou em nome de Deus para ser reconhecido como homem Santo. Assim, desta forma, quando ele começou a receber as revelações do Alcorão, pessoas muito importantes da cidade de Meca tentaram desmerecê-lo e fazer com que o povo desacreditasse de sua aproximação com Deus. Os seus inimigos tanto fizeram, que conseguiram expulsá-lo, bem como seus companheiros e seus familiares da cidade de Meca. Assim sendo, encontrou refúgio na cidade de Medina no ano de 622 d.C.; esta data acabou por ser conhecida como "Hégira". A luta de Maomé é contada dos versículos 540 ao 559, nas páginas 912 a 920 desse mesmo capítulo do Alcorão.

De acordo com Kamel (2007, p. 72), Maomé no segundo ano da Hégira conseguiu uma impotente vitória tendo ao seu lado apenas 303 homens, 70 camelos e 2 cavalos, conseguiu derrotar um exército, que era sem sombra de dúvida muito superior as suas forças. $\mathrm{O}$ exército da cidade de Meca continha mil homens muito bem equipados. $\mathrm{Na}$ época, os muçulmanos acreditavam que Maomé e seus homens tinham sido ajudados por uma legião de arcanjos pra que uma façanha dessas acontecesse; só seria possível mesmo contando com a ajuda divina.

Os versículos 1511 e 1559 das páginas do Alcorão 1215 e 1223, ainda darão uma contribuição com duas passagens sobre conflitos que poderia levar o povo muçulmano a interpretar as escrituras, equivocadamente. Primeiro, o versículo 1511, diz que as "querelas ${ }^{6}$ individuais" são mais fáceis de serem resolvidos; - se uma parte individual quisesse guerra, toda a comunidade deveria combatê-la, a condição essencial de paz é melhor do que a guerra, assim expressa o Alcorão.

Em segundo lugar, o Alcorão relata sobre um livro de Moisés que também fala de guerra, o livro das guerras de Jeová que tem o seguinte enunciado: "Livro de Moisés:

\footnotetext{
${ }^{5}$ Segundo o dicionário online de português Hégira: foi a fuga de Maomé, de Meca sua cidade natal, para Medina, no ano 622 da era cristã; a era maometana que teve seu início nesse ano.

${ }^{6}$ Segundo o Dicionário Prático da Língua Portuguesa Michaelis (2001, p. 719). Querela é (lat querela) sf - 1 Denúncia que se faz contra alguém diante de um Juiz ou Tribunal. 2 Processo Judicial, Ação. 3 Pequenas questões. 4 Debates, discussão. 5 poét. Lamentos.
} 
aparentemente não se trata de Pentateuco $^{7}$ ou de Tora, mas de outros livros, agora perdidos. Por exemplo, o livro das Guerras de Jeová, mencionado no Antigo Testamento [...]" (BÍBLIA. NÚMEROS, 21:14, p. 209, \& ALCORÃO. NOTA DO AUTOR, 1559, p. 1223).

Algumas acusações foram atribuídas ao povo judeu no Alcorão (2006, versículo 376, p. 856), onde acusam esse povo de destorcerem os significados das escrituras do Alcorão ao seu próprio interesse, fazendo suas próprias interpretações. Pois, assim, já que eles possuíam as escrituras incompletas, seus temores eram maiores aos homens do que ao próprio Deus; diziam eles, que o quê eles possuíam eram nada mais nada menos do que "fragmentos das Leis originais" que fora revelada ao profeta Moisés ${ }^{8}$, junto com alguns assuntos semihistórico e legendário sem comprovação e sem autenticidade comprovada; por isso reescreviam as escrituras conforme aos seus interesses religiosos e políticos.

\section{ORIGEM DO GRUPO TERRORISTA ESTADO ISLÂMICO}

Antes de falarmos da origem do Grupo Terrorista Estado Islâmico, recordaremos alguns fatos importantes que ocorrera no passado, que talvez possa ter influenciado na origem do mesmo.

Por volta dos anos de 1989, o saudita Osama Bin Ladem criou a "Rede de Terroristas Al-Qaeda", com o patrocínio e treinamentos de táticas militares ofertado pelo país, considerado hoje seu maior inimigo - os Estados Unidos da América e, com o apoio de outros grupos "fundamentalista Sunita", como o Talibã, com o objetivo de combater a invasão do Afeganistão, pela antiga União Soviética que já durava dez anos. Esse país o acolheu e lhe serviu de esconderijo por vários anos enquanto era procurado pelos seus algozes.

O Afeganistão, país de origem Islâmica na Ásia Central, tem fundamental importância por sua localização geográfica, e, é um dos pontos estratégicos para as relações econômicas e política, assim como militarmente a região é ponto estratégico. O Afeganistão sofreu ao longo dos séculos com inúmeras invasões em seu território, desde o Império Persa, com Alexandre o Grande, até os Celtas no século II a.C. (FRANCISCO, 2018).

\footnotetext{
${ }^{7}$ Pentateuco ou Tora: este nome em grego significa "cinco rolos", ou livros, e inclui Génesis, Êxodo, Levítico, Números e Deuteronômios. A autoria do Pentateuco, considerado como Lei de Moisés.

${ }^{8}$ A nota do autor no Alcorão, retrata uma passagem de uma guerra liderada por Moisés, onde assassinaram o Rei dos madianitas, mataram todos os homens e incendiaram suas casas, queimaras suas cidades e castelos, e tomaram posse do seu gado. (ALCORÃO.NOTA DO AUTOR, 509, p. 900, \& NÚMEROS, 31:7-11, p. 223).
} 
Neste período de criação da Al-Qaeda, Osama Bin Laden tinha ao seu lado, àquele que o considerava o seu "braço direito" e que o ajudou a fundar a organização terrorista, e chefe da "Ramificação" da mesma no Iraque, o jordaniano da cidade de Zarca - Abu Musab alZarqawi, cujo nome verdadeiro era Ahmed Fadel al Jalaylah de 40 anos.

Abu Musab al-Zarqawi também foi criador no ano de 1999, do grupo jihardista "Tawhid wa al-Jihad" em português (Grupo de Monoteísmo e Jihad), um braço armado da Al-Qaeda. Por volta do ano de 2002, quando os Estados Unidos resolveram invadir o Iraque, tendo como pretexto para essa invasão, os ataques terroristas em solo americano, que tiveram como alvos as "torres gemeas" do Wood Trade Center e ao Centro de Comando Militar dos Estados Unidos, o Pentágono, Abu Musab al-Zarqawi jura lealdade a Osama Bin Laden, e resolve criar as bases da Al-Qaeda em território iraquiano para fazer frente a invasão da coligação aliada (G1-MUNDO, 2015).

\section{Criação do grupo Estado Islâmico (ISIS) no Iraque e na Síria}

Após a morte de Abu Musab al-Zarqawi em 2006, vítima de um ataque surpresa, quando participava de uma reunião com os seus condescendentes e colaboradores na Aldeia de Hibib, no noroeste da cidade de "Baquba", na província de "Diyala", no Iraque, a AlQaeda cria um novo grupo - o Estado Islâmico (Isis), com características violentas e radicais sob o "jugo" de um novo líder conhecido como (califa, Abu Bakr al-Baghdadi). Poderíamos dizer que este radicalismo se remete a passoas intolerantes, que lutam por um proposito contraditóro, e tiram a vida de inoscentes em nome de Deus.

Embora o Ocidente os considere loucos, desequilibrado, fanaticos religiosos, eles têm um projeto político aldacioso, bem definido e estruturado que pretende acabar com os "infiés" ao redor do mundo, e fundar um califado (Estado independente), regido sob as leis Islâmicas, à Sharia, em todas as regiões do mundo que prega a religião do islã (BBC BRASIL, 2015).

Segundo notícias do "site" O Globo (2015), o grupo terrorista Estado Islâmico com a sigla "Isis" (Estado Islâmico no Iraque e na Síria), foi fundado no ano de 2013, como uma ramificação da Rede Terrorista Al-Qaeda, com a ajuda dos Estados Unidos e países aliados, no intuito de que esses grupos rebeldes desestabilizassem e destituísse os governos desses países pelo uso da força bélica. Mas o que os países do Ocidente e seus aliados no Oriente não esperavam, é que esses rebeldes fossem se desligar da aliança feita com a Al-Qaeda, fato que ocorreu no ano de 2014 G1-Mundo (2015), e quisessem reivindicar territórios no Iraque e na 
Síria para formar um califado. Isso passou a ser feito com a promoção de ataques terroristas, sequestrando e matando pessoas em seu próprio território e de várias outras nacionalidades que se opusessem a eles.

O Estado Islâmico se tornou "superlativo" aos demais grupos terroristas, e começou a se mostrar para o mundo de forma contundente depois que assume o atentado terrorista ao jornal francês "Charlie Hebdo", em janeiro de 2015, quando alguns jornalistas desse "tabloide" começaram a publicar charges com conteúdo de ofensas religiosa a Maomé, episódio que revoltou todas as Comunidades Muçulmanas. Entretanto, sobre a veracidade da autoria deste atendado reivindicado pelo Estado Islâmico, "paira" uma contradição, já que o grupo terrorista da Al-Qaeda do Iêmen, na época do ataque, também reivindicou em vídeo, a autoria desse mesmo atentado.

$\mathrm{O}$ ataque deixou um saldo de doze mortos e cinco feridos. A partir daí, o grupo vem se "insurgindo" como um dos grupos mais intolerantes e violentos para com àqueles que se opõe as suas posições. Por conta disso, promove e reivindica atentados violentos em locais públicos, com o intuito de fazer o maior número possível de vítimas civis, conseguindo chamar a atenção do mundo inteiro, tentando evidenciar a fragilidade da segurança pública de algumas nações sobretudo da Europa, quando na verdade, essas nações vivem num patamar de insegurança muito forte; é por isso, que o excesso de segurança acaba por ferir as liberdades democráticas. A partir dessas restrições, os grupos tentam implantar o terror e o medo tanto na população em civil geral, como nos agentes públicos.

\section{Cronologia dos ataques reevindicados pelo Estado Islâmico entre 2014 e 2016 na Europa, África e Ásia}

A Assembleia Geral das Nações Unidas AGNU (2017), desenvolveu um trabalho bastante interessante, e por outro lado, muito importante no que tange os ataques do grupo Estado Islâmico (EI) em alguns continentes, para podermos entender como se dá a geopolítica transfronteiriça do terrorismo e a espacialização geográfica dos pontos que sofreram com ataques terroristas fora do Iraque e da Síria, países que tentam combater o terrorismo, se opondo as tentativas de o grupo formar um "califado". Esses pontos se concentram em países que se dizem aliados dos ocidentais, principalmente dos Estados Unidos. Como é possível observar na figura -1. 
Figura 1: mostra os ataques espalhados pelo mundo. Na legenda em azul, inspirado pelo (EI) e em vermelho, realizado pelo mesmo, ou por afiliados

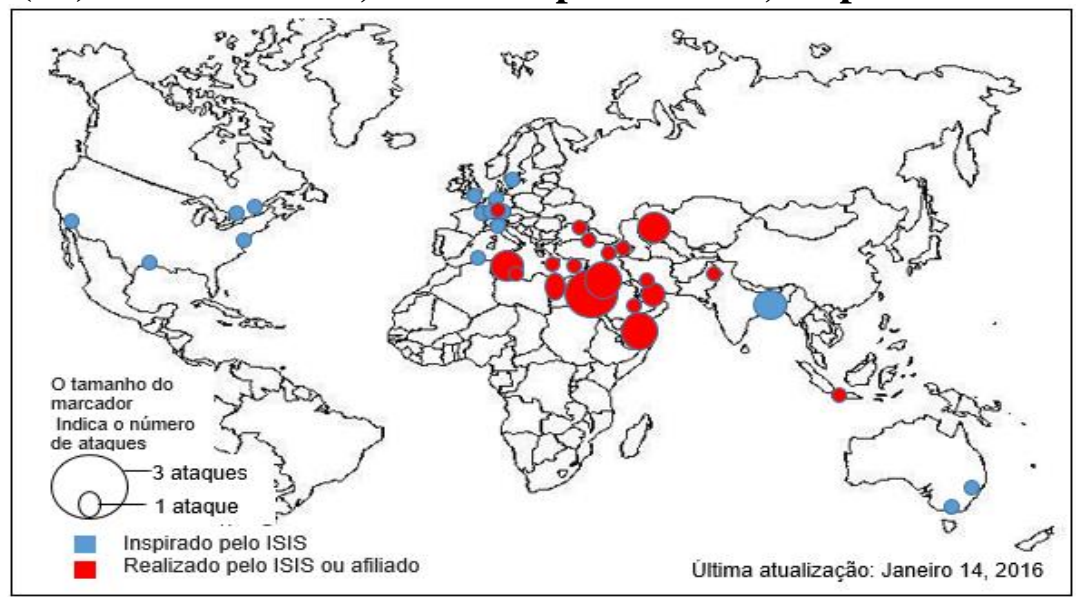

Fonte: AGNU, 2017 (adaptado pelo autor).

A cor vermelha, a quantidade de ataques se concentram no Oriente Médio e na parte do norte e nordeste da África. Esses ataques são atribuídos ao Estado Islâmico e seus afilados, por estarem em seu território de domínio. Eles são de quantidade bem maior do que os de cor azul, por serem ataques de outras ramificações inspirados no Estado Islâmico, ou seja, os pontos de cor azul, são promovidos por outros grupos que procuram usar as mesmas táticas desse grupo terrorista.

Depois da suposta autoria do atentado ao jornal "Charlie Hebdo" em janeiro de 2015, o grupo terrorista promove no ano de 2016 uma série de atentados na França e em outras partes da Europa, como é visto na figura - 2. Em 13 de novembro desse mesmo ano, Paris sofre mais seis ataques nos arredores do estádio de futebol (State de France), em restaurantes e no Teatro Bataclã, onde acontecia um evento, fazendo cerca de 130 vítimas fatais.

"Em 22 de março de 2016: Bruxelas, Bélgica - ataques quase que simultâneos no Aeroporto Internacional de Zaventem, enquanto o outro ocorreu no metrô da capital, na estação Maelbeek; pelo menos 35 pessoas morreram, enquanto que mais de 200 ficaram feridas" ver figura -2 . 
Figura 2: mostra os ataques espalhados pelo mundo. No Reino Unido, em azul, inspirado pelo (EI) e em vermelho, realizado pelo mesmo, ou por afiliados.

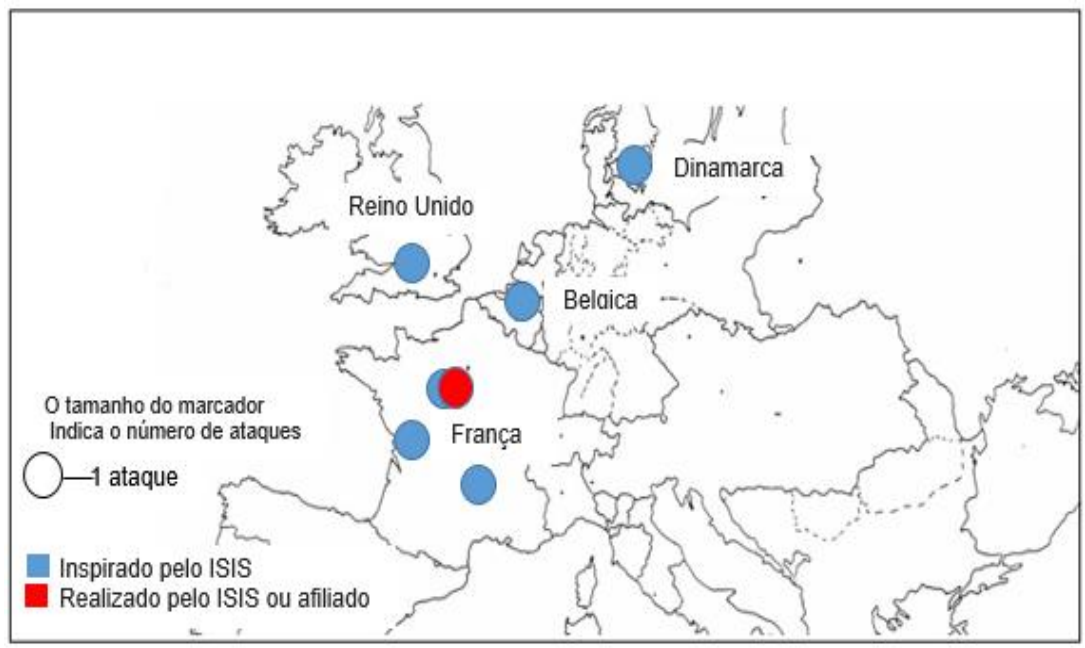

Fonte: AGNU, 2017 (adaptado pelo autor).

"Em 14 de julho de 2016: Nice, França - acontecia um evento em celebração ao Dia da Bastilha e, um caminhão guiado pelo franco-tunisiano Lahouaiej Bouhlel, atropelou as pessoas que assistiam a queima de fogos. No total, mais de 85 foram mortos, e outros 40 feridos. O Estado Islâmico reivindicou o ataque embora o serviço de inteligência francês não tenha encontrado nenhuma ligação entre Bouhlel e a organização terrorista" ver figura - 3 .

Figura 3: mostra os ataques espalhados pelo mundo realizado pelo (EI), em Nice, sul da França - Normandia, França - Ansbach, Alemanha - Wurzburgo, Alemanha.

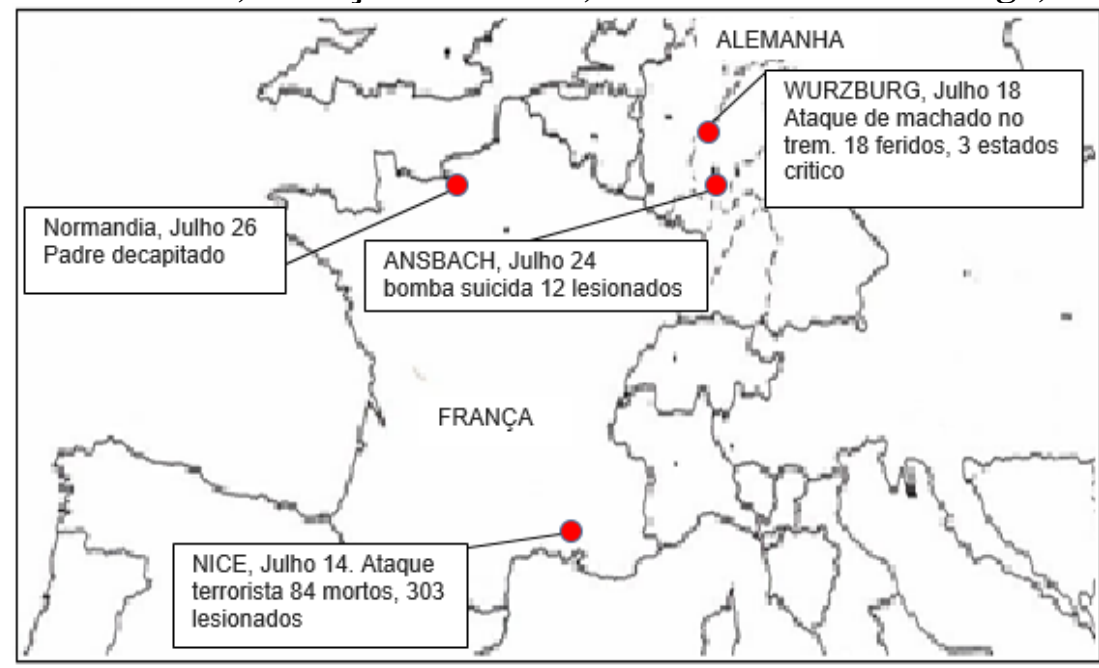

Fonte: AGNU, 2017 (adaptado pelo autor).

"Em 28 de julho de 2016: Istambul, Turquia - Uma das principais cidades da Turquia também foi alvo do grupo, que enviou três homens bombas ao Aeroporto Internacional de 
Istambul. Os ataques ocasionaram a morte de 42 pessoas, e deixou mais de 240 feridos" ver figura -4 .

Figura 4: mostra os ataques espalhados pelo mundo. Na legenda em azul, inspirado pelo (EI) e em vermelho, realizado pelo mesmo, ou por afiliados. No Oriente Médio e Norte da África.

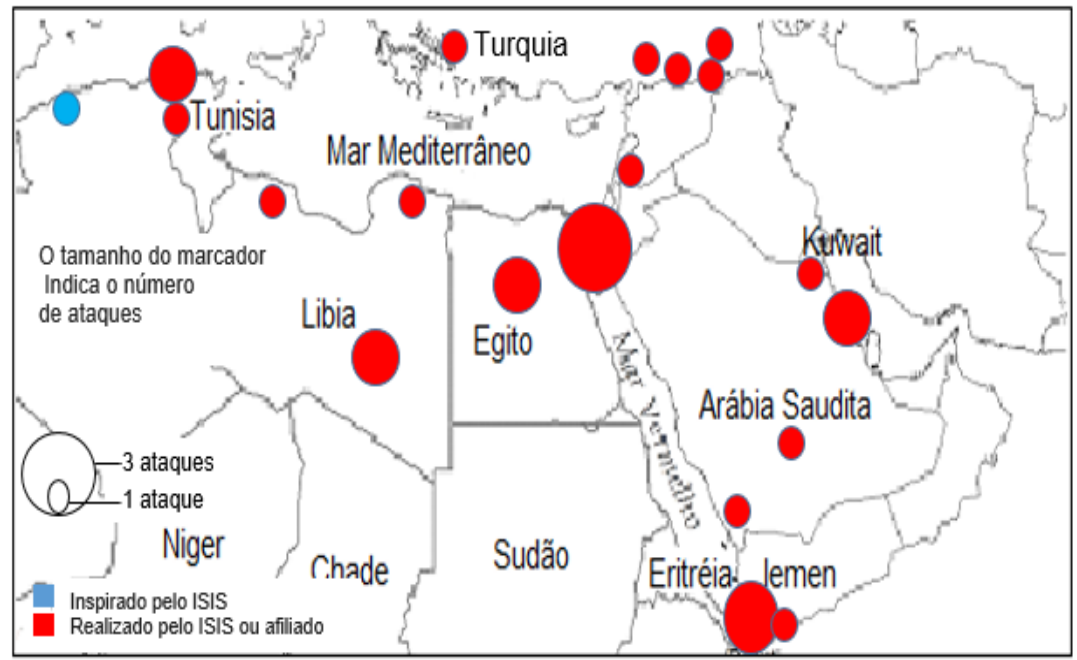

Fonte: AGNU, 2017 (adaptado pelo autor).

“Em 23 de julho de 2014: Cabul, Afeganistão - Xiitas protestavam numa manifestação contra a construção de uma usina, e durante o ato, dois membros do Estado Islâmico detonaram o cinturão explosivo que carregavam, ocasionando a morte de 80 civis e gerando mais de 240 feridos", como está mostrado os pontos dos atentados na figura -5 .

Figura 5: mostra os ataques espalhados pela Ásia. No Oriente Médio e Sudeste asiático. Na legenda em azul, inspirado pelo (EI) e em vermelho, realizado pelo mesmo, ou por afiliados.

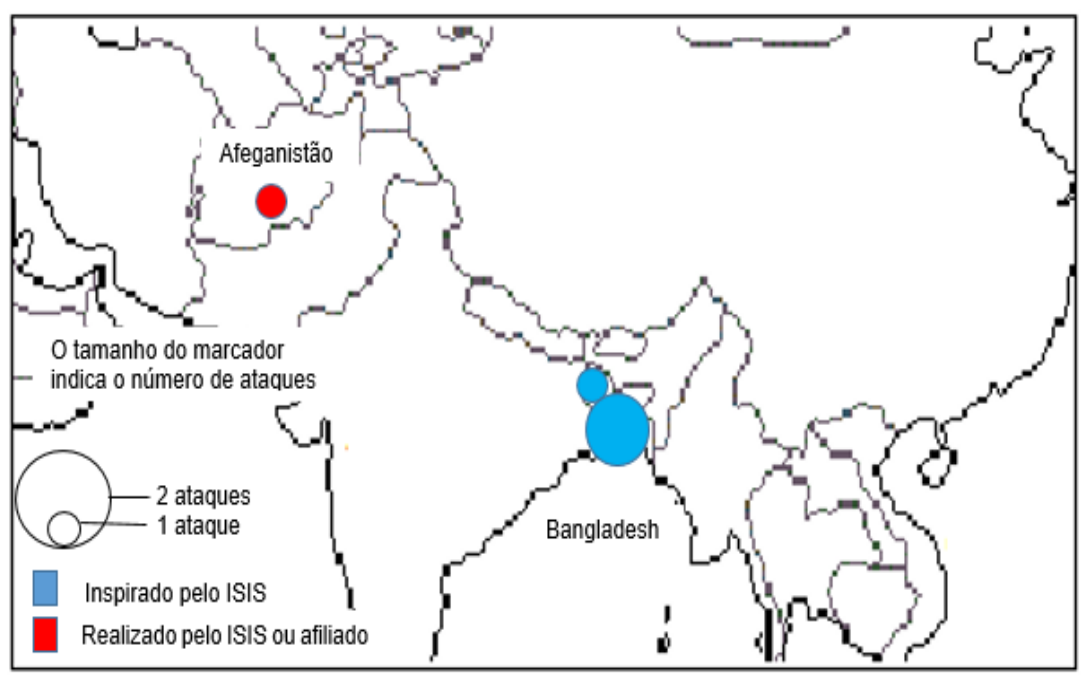

Fonte: AGNU, 2017 (adaptado pelo autor). 
“A maioria dos ataques aqui citados, ocorrem em países que atualmente estão mobilizados no combate ao grupo nos territórios da Síria e do Iraque, como é o caso da Bélgica, França e Turquia; já no caso do Afeganistão, o Estado Islâmico possui interesse em controlar a região e conta com um alto número de membros no país".

Alguns especialistas em segurança nacional e terrorismo, afirmam que os ideais do grupo eram apenas de dominar parte da região da Síria e do Iraque para satisfazer seus objetivos. Esses ideais passaram a ser bem maiores, ou seja, eles passaram a planejar uma política de expansão transfronteiriça, promovendo ataques terroristas ao redor do mundo para intimidar quaisquer ações, demandar poder, visando ampliar seu território, anexando partes dos países onde estaria estruturado, formando um grande califado, sem serem importunados.

Esta ideologia do Estado Islâmico de formar um califado com os territórios de origem islâmica pelo mundo, assemelha-se muito às ideias do conceito do "Pan-islamismo" (Movimento religioso e político que procura reunir num só Estado-nação, todos os povos de religião muçulmana). Este termo é ressaltado pelo geógrafo e escritor Yves Lacoste, autor do livro A Geopolítica do Mediterrâneo, assim como o termo "Sionismo":

O sionismo foi também um movimento nacional: visa teoricamente reunir num determinado território todos os membros ou a maioria dos membros daquilo que era considerado o povo judeu, de forma a que deixasse de ser objecto de descriminação e formasse finalmente uma nação independente como as outras (LACOSTE, 2006, p. 418-419).

Esse movimento não foi bem aceito pelas comunidades judaicas; - primeiro porque o povo estava espalhado por diferentes e vastos território no continente europeu; - segundo, os membros deste povo judeu falavam línguas diferentes, além de participar do desenvolvimento cultural de várias nações; - terceiro, os rabinos que são a base do judaísmo, reprovavam esse movimento, pelo fato de os idealizadores serem alguns poucos intelectuais sem vínculos com a religião e o território escolhido pelo movimento sionista para formar o Estado-nação. Eles alegavam que não era o local onde se encontra a maioria do povo judeu. 
Figura 6: mostra o começo da expansão islâmica desde a época do profeta Maomé.

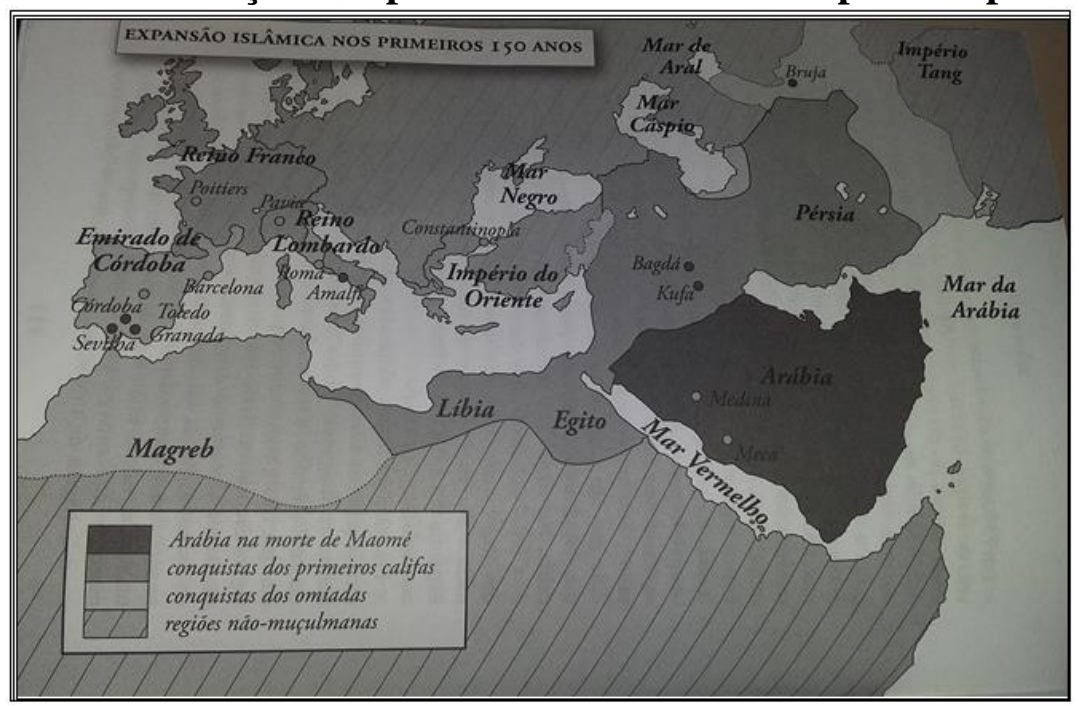

Fonte: KAMEL, Ali. 2007.

A ideia muçulmana de formar um califado vem desde os primórdios da história do islamismo, a data se remete desde a época do profeta Maomé, quando surgiu os primeiros califas na região da Arábia Saudita, em Meca e Medina. O mapa da região, da figura - 6, acima, mostra em sua legenda, o começo da expansão islâmica nos primeiros 150 anos de história do islã, desde a época de Maomé até as conquistas pelos califas que o sucederam.

\section{PROPOSITO DE CONQUISTA TRANSFRONTEIRIÇO DO GRUPO ESTADO ISLÂMICO}

O grupo Estado Islâmico após se desligar da rede terrorista Al-Qaeda, inicia a partir do ano de 2014, o seu propósito geopolítico/transfronteiriço de conquistar um vasto território na Síria e no Iraque para formar o tão desejado califado. E, é através da força e do poder de fogo das armas, que o grupo adquiriu com o passar do tempo, que eles vão tentar impor sua superioridade bélica aos soldados iraquianos e sírios durante algum tempo. A mancha amarela na figura -7 , dá a real dimensão do tamanho do território conquistado pelo grupo Estado Islâmico, transpassando as fronteiras de dois países, o Iraque e a Síria. 


\section{Figura 7: o Estado Islâmico começa a conquistar territórios e cidades importantes no Iraque e Síria para formar o califado.}

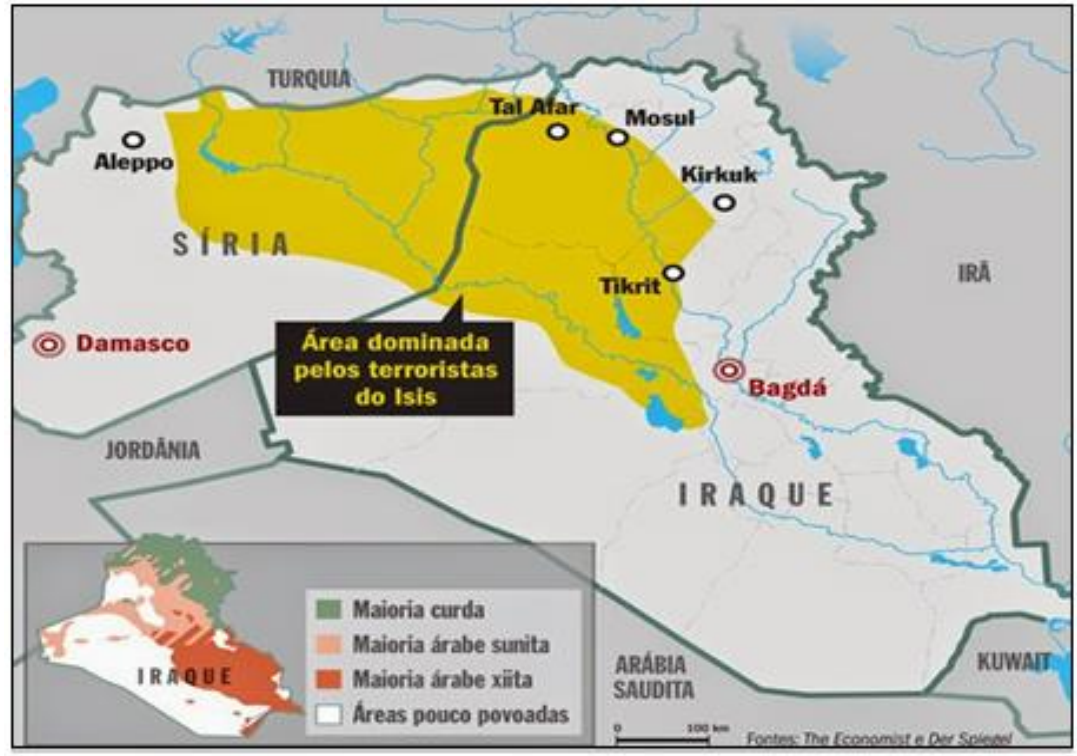

Fonte: Veja, 2014.

Os ideais do grupo Estado Islâmico são bastante audaciosos, comparando-se ao que pretende outros grupos terroristas que têm as mesmas características desse grupo. O califado que eles, os "jihadistas" pretendem implantar, vai muito além das fronteiras do Oriente médio, mais especificamente dos territórios do Iraque e da Síria, países de origem onde o grupo terrorista fora fundado. Seu real objetivo é conquistar todo o norte da África, incluindo o Magrebe $^{9}$, onde os países dessa região são de maioria mulçumana, uma parte do sul da Europa, península asiática e ainda a península ibérica, conhecida antigamente como Andaluzia $^{10}$, como mostra a figura -8 .

\footnotetext{
${ }^{9}$ O Magrebe ou Magreb é a região noroeste da África. Em sentido estrito, inclui Marrocos, Saara Ocidental, Argélia e Túnisia. O grande Magrebe inclui também a Mauritânia e a Líbia de religião islâmica. Na época do Império Romano, era conhecido como África Menor.

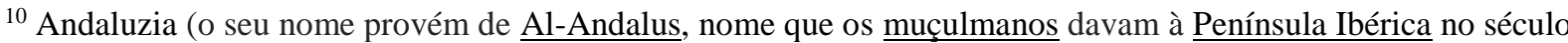
VIII. É a segunda maior comunidade autônoma espanhola e a mais populosa. Tornou-se comunidade autónoma em 1982. Segundo o seu estatuto autonômico, possui a condição de "nacionalidade histórica".
} 
Figure 8: pretendido pelo califado do grupo Estado Islâmico.

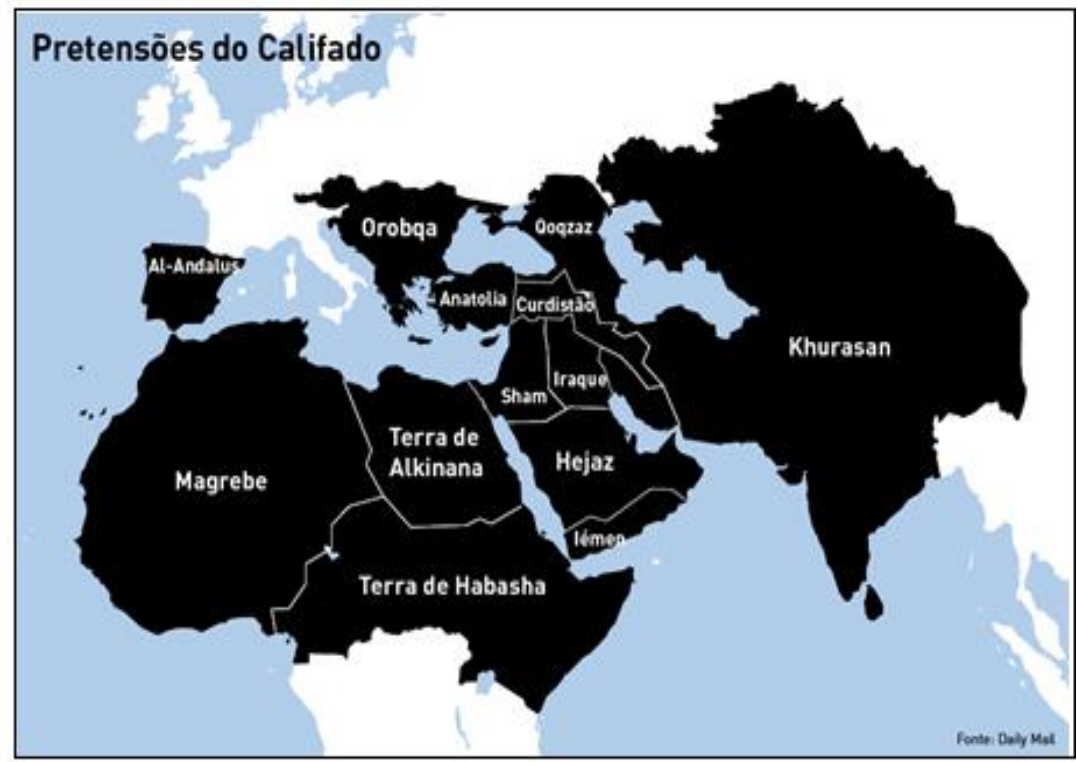

Fonte: Daily Mail, 2017.

\section{O Estado Islâmico começa a perder território gradativamente para as forças iraquianas e sírias com a ajuda da coalisão}

Como conta a história, nenhum império, ditadura ou califado se sustenta para sempre. Não seria diferente com a tentativa de formação de califado do grupo terrorista Estado Islâmico, que foi do apogeu à derrocada em pouco mais de três anos. Os países vêm cada vez mais intensificando as investidas contra esse grupo terrorista, em resposta à série de ataques promovidos pelo mesmo nos últimos tempos, cujo o alvo principal são as pessoas comuns que não têm nada a ver com os problemas geopolíticos entre governos e grupos radicais. Esse público se tornou vítima dos extremistas, pelo fato de serem mais vulneráveis e mais fáceis de serem atingidos numa proporção de magnitude mais devastadora.

Após três anos de muitas lutas contra os iraquianos e sírios, e depois de conquistarem cerca de $90.000 \mathrm{Km}^{2}$ de território desses dois países, para formar o tão pretendido califado, os radicais do grupo Estado Islâmico começam a partir de 2015, a perder essas áreas gradativamente para as forças militares desses mesmos países com a ajuda dos Estados Unidos e da coalisão aliada. A figura - 9, mostra exatamente essa retração do território perdido pelo grupo desde o ano de 2015, até os dias atuais, quando cidades iraquianas e sírias como Manbij, Raqqa e Mossul consideradas muito importantes tanto para os países, como para o grupo, foram retomadas e reintegradas de volta ao controle dos Estados. Recentemente o grupo perdeu as suas últimas cidades de domínio no território sírio, a cidade de Deir Ezzor, 
e Al-Qaim no território iraquiano. Isso implica numa conquista muito significativa para o início do fim definitivo do tão temido grupo (IHS BBC, 2016).

\section{Figura 9: mapa da retração territorial do grupo Estado Islâmico de 2015 até os dias} atuais.

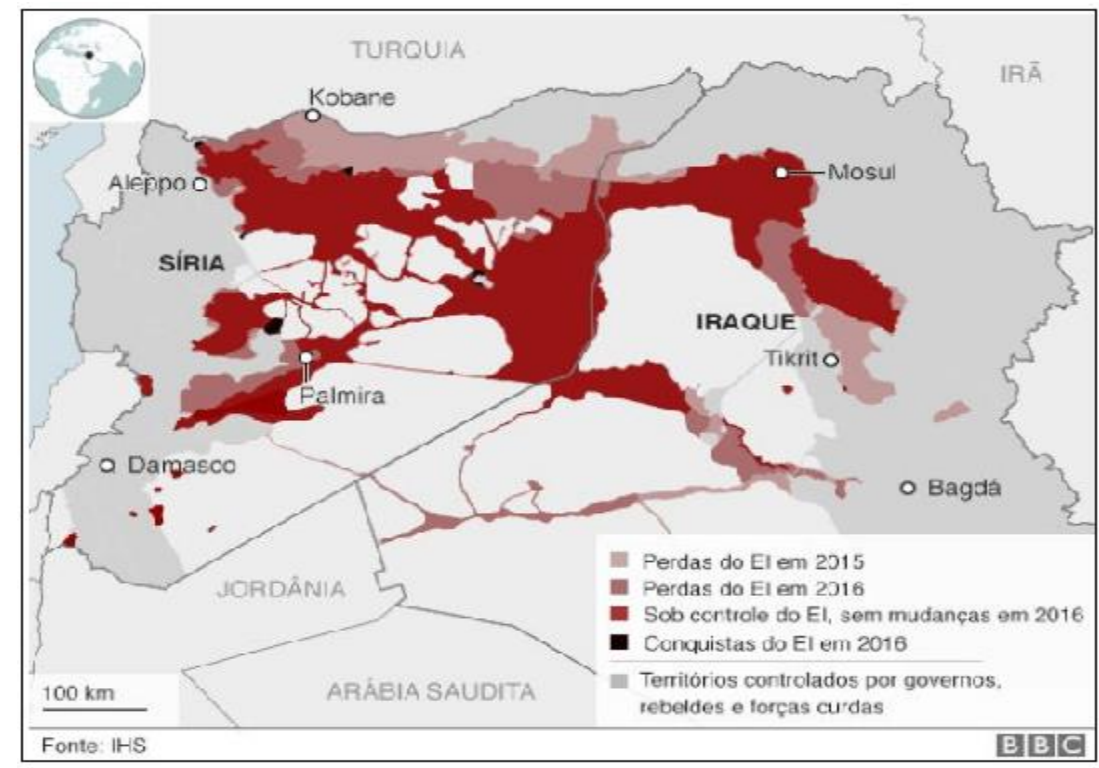

Fonte: IHS - BBC, 2016.

\section{CONSIDERAÇÕES FINAIS}

O mundo nos últimos tempos vem passando por muitas instabilidades econômicas e políticas, num cenário pós-globalização. Esta segunda questão, a questão política, deixa ainda mais um sentimento de fragilidade pelo alto número de conflitos armados, pela disputa de territórios e a obtenção dos recursos naturais que produzam energia. É comum na contemporaneidade observar que está havendo grandes turbulências, dentre elas, ameaças terroristas; ameaças essas, que podem acontecer em qualquer lugar do mundo, sem aviso prévio, e sem nenhum precedente. $\mathrm{O}$ acontecimento desses fatos se dá simplesmente para causar o terror, à instabilidade política e aumentar à falta de confiança na capacidade que os países têm de promover a segurança interna do seu território e de suas fronteiras.

No caso específico do tema em questão, fica muito difícil fecharmos o assunto de forma conclusiva e definitiva, pelo fato de as ações dos terroristas do grupo Estado Islâmico, tomarem um dinamismo muito grande no que se refere aos atentados promovidos pelo mesmo, já que a cada semana ou a cada mês, surge um fato novo envolvendo as investidas de atentados terroristas em uma parte qualquer do mundo, principalmente em alguns países da Europa e no Oriente Médio, onde os atentados tem uma maior constância. 
Sabe se que, em tempos remotos, outras religiões como o catolicismo e o cristianismo também promovia atos violentos como a "Santa Inquisição", que condenou à morte milhares de pessoas. "É mesmo uma lastima que os grupos radicais de ambos os lados contribuam para que, no mundo de hoje, o Islã, tenha para muitos, uma imagem de violência”.

Muitas vezes o Grupo Estado Islâmico reivindica atentados que não existe comprovação de que esses supostos atentados foram promovidos pelo grupo. Sabe-se que esse terrorismo tem como fundamento, resposta a atos de desprezo e preconceito ao islamismo, pois por décadas esse povo sofre não só pela opressão dos colonizadores na tentativa de dominação do Oriente, pelo Ocidente, mas também por líderes políticos dessa região que foram formados nas "academias" ocidentais, em geral na Europa, que visam objetivos econômicos, e não tem nenhum compromisso real com a religião.

Portanto, dessa maneira podemos entender que essa é uma área aberta para férteis discussões, que devem ser embasadas nos estudos geopolíticos e geoeconômicos da atualidade, e de uma nova forma de fazer guerra no mundo contemporâneo.

\section{REFERÊNCIAS BIBLIOGRÁFICAS}

AGNU, Assembleia Geral das Nações Unidas, (2017) - $17^{\circ}$ MINIONU. Os ataques terroristas reivindicados pelo Estado Islâmico. Publicado em 22 de setembro de 2016, por 17 minionuagnu 2017. Disponível https://17minionuagnu2017.wordpress.com/2016/09/22/os-ataques-terroristas-reivindicadospelo-estado-islamico/> . Acesso em: 24 de outubro de 2017.

ALCORÃO. AL 'ALAC, 96,1-5 (o Coágulo). In: O ALCOÃO Sagrado. Tradução, Introdução e Anotações. Samir El Hayek. Fontes digitais: Centro Cultural Beneficente Árabe Islâmico de Foz do Iguaçu, 2006, 1322 p. Disponível em: <http://www.ebooksbasil.org/adobeebook/alcorao.pdf>. Acesso em: 23/11/2016, p. 714-715).

ALCORÃO. INTRODUÇÃO. In: O ALCOÃO Sagrado. Tradução, Introdução e Anotações. Samir El Hayek. Fontes digitais: Centro Cultural Beneficente Árabe Islâmico de Foz do Iguaçu, 2006, 1322 p. Disponível em: <http://www.ebooksbrasil.org/adobeebook/alcorao.pdf>. Acesso em: 23/11/2016, p. 4-21).

ALCORÃO. MOHAMMAD, 47:4. (Maomé). In: O ALCOÃO Sagrado. Tradução, Introdução e Anotações. Samir El Hayek. Fontes digitais: Centro Cultural Beneficente Árabe Islâmico de Foz do Iguaçu, 2006, 1322 p. Disponível em: <http://www.ebooksbrasil.org/adobeebook/alcorao.pdf $\geq$. Acesso em: 23/11/2016, p. 564568).

ALCORÃO. NOTA DO AUTOR, 19. In: O ALCOÃO Sagrado. Tradução, Introdução e Anotações. Samir El Hayek. Fontes digitais: Centro Cultural Beneficente Árabe Islâmico de Foz do Iguaçu, 2006, 1322 p. Disponível em: 
<http://www.ebooksbrasil.org/adobeebook/alcorao.pdf $>$. Acesso em: 23/11/2016, p. 7341321).

80. In:

O ALCOÃO Sagrado. Tradução, Introdução e

Anotações. Samir El Hayek. Fontes digitais: Centro Cultural Beneficente Árabe Islâmico de Foz do Iguaçu, 2006, 1322 p. Disponível em: <http://www.ebooksbrasil.org/adobeebook/alcorao.pdf >. Acesso em: 23/11/2016, p. 7341321).

376. In:

O ALCOÃO Sagrado. Tradução, Introdução e

Anotações. Samir El Hayek. Fontes digitais: Centro Cultural Beneficente Árabe Islâmico de Foz do Iguaçu, 2006, 1322 p. Disponível em: <http://www.ebooksbrasil.org/adobeebook/alcorao.pdf >. Acesso em: 23/11/2016, p. 7341321).

509. In:

O ALCOÃO Sagrado. Tradução, Introdução e

Anotações. Samir El Hayek. Fontes digitais: Centro Cultural Beneficente Árabe Islâmico de Foz do Iguaçu, 2006, 1322 p. Disponível em: <http://www.ebooksbrasil.org/adobeebook/alcorao.pdf >. Acesso em: 23/11/2016, p. 7341321).

540-559. In:

O ALCOÃO Sagrado. Tradução, Introdução e

Anotações. Samir El Hayek. Fontes digitais: Centro Cultural Beneficente Árabe Islâmico de Foz do Iguaçu, 2006, 1322 p. Disponível em: <http://www.ebooksbrasil.org/adobeebook/alcorao.pdf>. Acesso em: 23/11/2016, p. 7341321).

1511-1559. In:

O ALCOÃO Sagrado. Tradução, Introdução e

Anotações. Samir El Hayek. Fontes digitais: Centro Cultural Beneficente Árabe Islâmico de Foz do Iguaçu, 2006, 1322 p. Disponível em: <http://www.ebooksbrasil.org/adobeebook/alcorao.pdf>. Acesso em: 23/11/2016, p. 7341321).

1559. In:

O ALCOÃO Sagrado. Tradução, Introdução e

Anotações. Samir El Hayek. Fontes digitais: Centro Cultural Beneficente Árabe Islâmico de Foz do Iguaçu, 2006, 1322 p. Disponível em: <http://www.ebooksbrasil.org/adobeebook/alcorao.pdf >. Acesso em: 23/11/2016, p. 7341321).

BBC, BRASIL. Sete perguntas para entender o 'Estado Islâmico' e como ele surgiu. $2015 . \quad$ Disponível em: <http://www.bbc.com/portuguese/noticias/2015/11/151114_estado_islamico_entenda_rb>. Acesso em: 05 de abril de 2017.

BÍBLIA. A.T. Êxodo 32:27-28. In: A BÍBLIA Sagrada. Contendo o antigo e o novo testamento. Pe. José Ulysses da Silva. Provincial dos Missionários Redentoristas de São Paulo: Reprodução da Bíblia Sagrada publicada pela DIFUSORA BÍBLICA dos Missionários Capuchinhos de Portugal $-8^{\circ}$ edição 1978. Editora Santuário. Adaptação conforme a ortografia e linguagem do Brasil. Aparecida - SP. 15 de setembro de 1982, p. 76-133. 
BÍBLIA. A.T. Números, 21:14. In:

A BÍBLIA Sagrada. Contendo o antigo e o novo testamento. Pe. José Ulysses da Silva. Provincial dos Missionários Redentoristas de São Paulo: Reprodução da Bíblia Sagrada publicada pela DIFUSORA BÍBLICA dos Missionários Capuchinhos de Portugal $-8^{\circ}$ edição 1978. Editora Santuário. Adaptação conforme a ortografia e linguagem do Brasil. Aparecida - SP. 15 de setembro de 1982, p. 175-231. 31:7-11. In:

A BÍBLIA Sagrada. Contendo o antigo e o novo testamento. Pe. José Ulysses da Silva. Provincial dos Missionários Redentoristas de São Paulo: Reprodução da Bíblia Sagrada publicada pela DIFUSORA BÍBLICA dos Missionários Capuchinhos de Portugal $-8^{\circ}$ edição 1978. Editora Santuário. Adaptação conforme a ortografia e linguagem do Brasil. Aparecida - SP. 15 de setembro de 1982, p. 209.

DINIZ, C. R. SILVA, I. B. da, Metodologia Cientifica. Tipos de Métodos e suas Aplicações. Universidade Federal do Rio Grande do Norte-UFRN. 2008.

EL PAÍS INTERNACIONAL, "Só quero ir para casa", diz a menina alemã que se uniu ao Estado Islâmico em Mossul. 2017. Disponível em: <https://brasil.elpais.com/brasil/2017/07/23/internacional/1500839407_085023.html>. Acesso em: 07 de janeiro de 2019.

FAISSOL, S. O Espaço, território, sociedade e desenvolvimento brasileiro. Rio de Janeiro: IBGE, 1994.

FRANCISCO, Wagner de Cerqueria e. "Afeganistão"; Brasil Escola. Disponível em <https://brasilescola.uol.com.br/geografia/afeganistao.htm>. Acesso em 01 de setembro de 2018.

G1-MUNDO NOTÍCIA. Sete perguntas para entender o 'Estado Islâmico' e como ele surgiu. 2015.

Disponível em: <http://g1.globo.com/mundo/noticia/2015/11/sete-perguntas-para-entender-oestado-islamico-e-como-ele-surgiu.html>. Acesso em: 05 de abril de 2017.

GONÇALVES, Rainer. História do Mundo. Alcorão, o livro sagrado dos mulçumanos.

Disponível em: <www.http://historiadomundo.uol.com.br/arabe/alcorao.htm>. Acesso em: 13 de dezembro de 2017.

IHS, BBC, Mapa de Retração do Território do Grupo Estado Islâmico, 2016. Disponível em: <http://www.bbc.com/portuguese/internacional-37601634>. Acesso em: 20 de dezembro de 2017.

MICHAELIS. Dicionário Prático da Língua Portuguesa. São Paulo. ed. Melhoramento. Série1. 2001, p. 719.

KAMEL, Ali. De Adão a Maomé. In: Sobre o Islã. A Afinidade Entre Mulçumanos, Judeus e Cristãos e as Origens do Terrorismo. Editor: Luciano Trigo. Revisão: Eduardo Carneiro, Maria Angélica Vieira, Shahira Mahmud. Editora Nova Fronteira. Rio de Janeiro, 2007. Cap. 1, p. 25-84.

KAMEL, Ali. Sunitas e Xiitas. In: Sobre o Islã. A Afinidade Entre Mulçumanos, Judeus e Cristãos e as Origens do Terrorismo. Editor: Luciano Trigo. Revisão: Eduardo 
Carneiro, Maria Angélica Vieira, Shahira Mahmud. Editora Nova Fronteira. Rio de Janeiro, 2007. Cap. 2, p. 87-119.

LACOSTE, Y. Israel e Palestina. In: A Geopolítica do Mediterrâneo. Edição 70. Tradução: Pedro Elói Duarte. Revisão: Pedro Bernardo. Lisboa, Portugal. 2006. Cap. 14, p. 417-454.

LACOSTE, Y. Um subconjunto geopolítico extremamente complexo. In: A Geopolítica do Mediterrâneo. Edição 70. Tradução: Pedro Elói Duarte. Revisão: Pedro Bernardo. Lisboa, Portugal. 2006. Cap. 12, p. 391-403.

O ALCORÃO SAGRADO. Tradução, Introdução e Anotações. Samir El Hayek. Fontes digitais: Centro Cultural Beneficente Árabe Islâmico de Foz do Iguaçu, 2006, 1322 p. Disponível em: <http://www.ebooksbrasil.org/adobeebook/alcorao.pdf $>$. Acesso em: 23/11/2016.

O GLOBO. Cinco pontos para entender o Estado Islâmico, grupo que aterroriza Iraque e Síria. 2015. Disponível em: <http://infograficos.oglobo.globo.com/mundo/cinco-pontospara-entender-o-grupo-isis.html>. Acesso em: 05 de abril de 2017.

RAFFESTIN, Claude. Por uma Geografia do Poder. São Paulo: Ática, 1993.

RAMONET, Ignácio. Geopolítica do Caos. 1998. Tradução: Guilherme João de Freitas Teixeira. $4^{\text {a }}$ edição. Editora Vozes - Petrópolis, RJ, 2001, p. 7.

RTP-NOTÍCIAS. Pretensão do Califado. 2017. Disponível em: $<$ http://media.rtp.pt/estadoislamico/mapas/califado>. Acesso em: 20 de dezembro de 2017.

SANTOS, M.; SOUZA, M. A. de; SILVEIRA, M. L. ( org ) Território; Globalização e Fragmentação. Huctec, 1999.

VEJA. Mundo. Jihadistas tomam a maior cidade cristã do Iraque. de Domínio do Grupo Estado Islâmico no Iraque e na Síria. Disponível em: $<$ https://veja.abril.com.br/mundo/jihadistas-tomam-a-maior-cidade-crista-do-iraque/>. Acesso em: 21 de dezembro de 2017.

Recebido em Setembro de 2018

Aprovado em Dezembro de 2018

Publicado em Fevereiro de 2019 